\title{
Wet faeces produced by sheep fed dried spineless cactus pear cladodes in balanced diets
}

\author{
H.O. de Waal ${ }^{\#}$, D.C. Zeeman and W.J. Combrinck \\ Department of Animal, Wildlife and Grassland Sciences, University of the Free State, P.O. Box 339, Bloemfontein \\ 9300, South Africa
}

\begin{abstract}
Cactus pear cladodes in ruminant diets are characterized by the production of wet faeces and assumed to be diarrhoea. Incremental levels of sun-dried and coarsely ground spineless cactus pear (Opuntia ficusindica var. Algerian) cladodes were used to substitute part of the lucerne hay in balanced sheep diets. Feed and water intake and faeces and urine excretion were determined with 24 Dorper wethers. The four diets (T0, T12, T24 and T36) comprised respectively (air dry basis) 0, 120, 240 or $360 \mathrm{~g} / \mathrm{kg}$ sun-dried, coarsely ground Opuntia cladodes; 660, 535, 410 or 285 g/kg coarsely ground lucerne hay; 300 g/kg yellow maize meal; 0, 5, 10 or $15 \mathrm{~g} / \mathrm{kg}$ feed grade urea; and $40 \mathrm{~g} / \mathrm{kg}$ molasses meal. The wethers drank significantly more water with increasing inclusion of Opuntia in the diets, while urine excretion showed little increase. Food intake and faeces dry matter (DM) excreted remained the same for all diets, but the DM content of the faeces decreased with higher levels of Opuntia inclusion. The wetter faeces produced by the sheep lacked the customary foul smell associated with diarrhoea and this is ascribed to the water-binding capacity of the mucilage in Opuntia. Although more definitive research is needed, it is concluded that the wetter faeces produced by the sheep on diets T12, T24 and T36 were not diarrhoea induced by the sun-dried and coarsely ground Opuntia cladodes, but the result of larger quantities of water that were not reabsorbed from the lower digestive tract.
\end{abstract}

Keywords: Cactus pear, diarrhoea, feed intake, mucilage, water intake

"Corresponding author. Email: dewaalho.sci@mail.uovs.ac.za

\section{Introduction}

The cladodes of spiny and spineless cactus pears are used as feed for livestock during the frequent periods of food shortages or droughts in many arid and semi-arid regions (De Kock \& Aucamp, 1970; Felker, 1995; Pretorius et al., 1997; Ben Salem et al., 2002; Tegegne, 2002b; Batista et al., 2003). Spineless cactus pears are valued by many farmers because of their drought resistance, high biomass yield, palatability and adaptability to a range of soils and climatic regions (Ben Salem et al., 1996; Batista et al., 2003). Spineless cactus pear cladodes have a very high water content (Felker, 1995) and when fed to animals little, if any, additional water is needed. However, a distinct concern when feeding spineless cactus pear cladodes to ruminants is the production of very wet faeces or diarrhoea, presumably caused by its laxative effect (Ben Salem et al., 2002).

Spineless cactus pear (Opuntia ficus-indica) varieties are grown in South Africa for fruit production aimed at export markets and have recently increased considerably (Claassens \& Wessels, 1997). Production of Opuntia fruits is stimulated by annual pruning and creates the opportunity to utilize the large quantities of cladodes as livestock feed. An important challenge is to dry the large volume of cladodes effectively, thus enabling it to be transported to where it is needed as livestock feed. A practical drying method will also enable farmers with small cactus pear orchards to store pruned material as a feed for their livestock.

A study was conducted to evaluate the inclusion of incremental levels of sun-dried and coarsely ground $O$. ficus-indica var. Algerian cladodes in balanced sheep diets as partial substitution of coarsely ground lucerne hay. Use of substantial quantities of sun-dried and coarsely ground Opuntia cladodes may turn a waste product into a valuable livestock feed. However, excretion of very wet faeces makes Opuntia less attractive as a feed source, especially when animals are confined to kraals or feedlots. This report aims to create a perspective on the phenomenon of wet faeces produced by Opuntia in balanced sheep diets. 


\section{Materials and Methods}

Cladodes produced during the growing seasons of 2002/2003 and 2003/2004 were pruned on 12 May 2004 from 10 trees in a fruit bearing O. ficus-indica var. Algerian orchard in the Bloemfontein district. The cladodes yielded $1159 \mathrm{~kg}$ fresh plant material. The cladodes were cut lengthways by hand into strips of about 20-25 mm wide using a sharp, long bladed butcher's knife and the strips were packed in a single layer on wire racks and dried in the sun. This facilitated air movement around the cladode strips to promote faster drying. After a week of drying in the winter sun (second half of May 2004), the cladode strips were curled up and the cut wounds covered with white callus material, which reduced the effectiveness of the drying process to some extent. The partially dried cladode strips were then ground to pass through a $20 \mathrm{~mm}$ sieve in a hammer mill. A sieve with a fairly large aperture size of $20 \mathrm{~mm}$ was used in this study (Zeeman, 2005) and not, as suggested by Nefzaoui \& Ben Salem (2000), a sieve with a much smaller aperture size of $6 \mathrm{~mm}$. Cut cactus pear cladode pieces should dry within a week (Terblanche et al., 1972). However, in this study all the material was not completely dry even after a week, therefore, the freshly ground material was spread out again on a clean, dry cement floor in the sun for further drying. The ground and partially dried material was turned over occasionally to prevent it from moulding. During the first grinding, larger pieces of cladode strips were still relatively moist and flexible enough to pass unchanged through the $20 \mathrm{~mm}$ sieve. Therefore, the ground plant material was ground a second time after further drying through the $20 \mathrm{~mm}$ sieve. This more homogenous material was used to substitute part of ground lucerne hay in balanced sheep diets (Table 1). The lucerne hay was also ground to pass through the $20 \mathrm{~mm}$, while the coarsely ground yellow maize meal, feed grade urea and molasses meal were included in the diets in the physical form in which they were acquisitioned. This was done to formulate and constitute diets which could be applied with a minimum of further processing and with direct application on farms. Diets were mixed thoroughly with a garden spade on a clean cement floor.

Table 1 The air dry (g/kg feed) composition of the four treatment diets with incremental inclusion levels of sun-dried and coarsely ground Opuntia cladodes

\begin{tabular}{lrrrr}
\hline \multirow{2}{*}{ Feeds } & \multicolumn{4}{c}{ Treatment diets $^{*}$} \\
\cline { 2 - 5 } & T0 & T12 & T24 & T36 \\
\hline Coarsely ground Opuntia cladodes (kg) & 0 & 120 & 240 & 360 \\
Coarsely ground lucerne hay (kg) & 660 & 535 & 410 & 285 \\
Yellow maize meal (kg) & 300 & 300 & 300 & 300 \\
Feed grade urea (kg) & 0 & 5 & 10 & 15 \\
Molasses meal (Calori 3000) (kg) & 40 & 40 & 40 & 40 \\
\hline
\end{tabular}

${ }^{*}$ Inclusion levels of coarsely ground Opuntia cladodes: T0 - 0\%; T12-12\%; T24-24\%; and T36-36\%

Twenty four young Dorper wethers (body weight of $36 \pm 3.49 \mathrm{~kg}$ ) were stratified according to body weight and randomly allocated to four treatments (T0, T12, T24 and T36). Each treatment group was adapted to its diet over a period of nine days: after an initial adaptation period of five days outdoors in pens, they were weighed and randomly housed in individual metabolism crates for the last four days of adaptation to the diets and especially to get accustomed to the environment in metabolism crates. Feed intake and digestibility, as well as water intake and urine excretion were determined over 10 days; the metabolism crates were designed specifically to separate and collect the faeces and urine of male sheep separately. The wethers were fed in 24-hour cycles, starting at noon, followed by feeding at 16:30 and then at 08:30 the following morning. Based on a 3-day moving average of air dry feed intake of the preceding three days and a 15\% refusal level, the air dry feed of each wether for the next 24 hours was weighed in paper bags. If a wether ate all its weighed feed before the end of a 24-hour cycle, more feed was weighed and provided.

Three days into the 9-day adaptation period, most wethers on diets T24 and T36 began to produce wet faeces, reminiscent of diarrhoea. A dietary prophylactic of $0.7 \mathrm{~g}$ kaolin (hydrated aluminium silicate, $\mathrm{Al}_{2} \mathrm{O}_{3}$ $2 \mathrm{SiO}_{\mathrm{n}} 2 \mathrm{H}_{2} \mathrm{O}$ ) was given to all the wethers at every feeding to prevent excretion of wet faeces. This measure had no visible effect in reducing the excretion of wet faeces, but was routinely administered three times per day over the feed for the duration of the trial. 
The DM of faeces, feed refusals and composite feed samples were determined by drying in a force draught oven at $100{ }^{\circ} \mathrm{C}$ (AOAC, 2000). Samples were analysed for: organic matter (OM) content by incineration in a muffle furnace at $550{ }^{\circ} \mathrm{C}$ (AOAC, 2000); nitrogen $(\mathrm{N})$ content in a Leco ${ }^{\circledR}$ Nitrogen analyser (Leco, 2001) and $\mathrm{N}$ content converted to crude protein (CP) by a factor of 6.25; ether extract (EE) according to the AOAC (2000) procedures but by using hexane as solvent; and the acid detergent fibre (ADF) and neutral detergent fibre (NDF) according to the procedures described by Goering \& Van Soest (1970) and Robertson \& Van Soest (1981). The data was statistically analysed using GLM procedures of SAS (2001).

\section{Results and Discussion}

The DM content of the diets (Table 2) decreased with the increasing inclusion levels of Opuntia cladodes. Cactus pears are succulent plants and the material does not dry easily. This is ascribed to the mucilage, a hydrophilic mucus-like compound that has a high water-binding capacity (Cárdenas et al., 1997; Tegegne, 2002a; Sáenz et al., 2004). The precise function of the mucilage is not known, however, it is generally believed that it helps to retain water inside the cactus (Mindt et al., 1975; Sudzuki Hills, 1995); the ability of cacti to retain water under less favourable climatic conditions of prolonged drought is due in part, at least, to the water-binding capacity of mucilage (Mindt et al., 1975). It may in part explain the lower DM content of diets T24 and T36 (Table 2).

Table 2 Dry matter (DM) content and chemical composition of the four treatment diets with incremental inclusion levels of sun-dried and coarsely ground Opuntia cladodes

\begin{tabular}{lrrrr}
\hline & \multicolumn{4}{c}{ Treatment diets $^{*}$} \\
\cline { 2 - 5 } & \multicolumn{1}{c}{ T0 } & \multicolumn{1}{c}{ T12 } & \multicolumn{1}{c}{ T36 } \\
\hline Dry matter (g DM/kg feed) & 905.5 & 904.3 & 886.1 & 881.7 \\
Organic matter (g/kg DM) & 904.6 & 885.0 & 890.0 & 869.3 \\
Crude protein (g/kg DM) & 167.9 & 180.9 & 165.4 & 168.0 \\
Ether extract (g/kg DM) & 23.5 & 24.9 & 25.8 & 27.0 \\
Acid detergent fibre (g/kg DM) & 304.0 & 265.6 & 239.2 & 207.2 \\
Neutral detergent fibre (g/kg DM) & 470.8 & 410.2 & 410.0 & 315.0 \\
\hline${ }_{*}^{*}$
\end{tabular}

${ }^{*}$ Inclusion levels of coarsely ground Opuntia cladodes: T0 - 0\%; T12 - 12\%; T24 - 24\%; and T36 - 36\%

Wethers drank significantly $(\mathrm{P}>0.05)$ more water with increased inclusion of Opuntia in the diets, while urine excretion showed little increase (Table 3). Food DM intake and faeces DM excreted remained the same for all diets (Table 3), but the DM content of the faeces decreased with higher levels of Opuntia inclusion. The wetter faeces produced by the wethers lacked the customary foul smell associated with diarrhoea and this is ascribed to the water-binding capacity of mucilage contained in Opuntia. Wethers on diet T36 drank about $900 \mathrm{~mL}$ water/day more than those on diet T0, but only excreted $171 \mathrm{~mL}$ more urine.

Table 3 Mean ( \pm s.e.) feed intake (g DM/day) and water intake (mL/day) and urine ( $\mathrm{mL} /$ day) and faeces (g DM/day) excreted by Dorper wethers on diets with incremental inclusion levels of sun-dried and coarsely ground Opuntia cladodes

\begin{tabular}{|c|c|c|c|c|}
\hline & \multicolumn{4}{|c|}{ Treatment diets $^{*}$} \\
\hline & T0 & T12 & T24 & T36 \\
\hline Feed intake (g DM/day) & $1148.3^{\mathrm{a}} \pm 66.2$ & $1119.2^{\mathrm{a}} \pm 153.5$ & $1104.3^{\mathrm{a}} \pm 118.8$ & $1085.9^{a} \pm 162.7$ \\
\hline Water intake (mL/day) & $2235.5^{b} \pm 190.6$ & $2695.3^{\mathrm{ab}} \pm 595.5$ & $2949^{\mathrm{ab}} \pm 592.0$ & $3189.3^{a} \pm 775.6$ \\
\hline Urine excreted (mL/day) & $779.1^{\mathrm{a}} \pm 150.3$ & $811.8^{a} \pm 212.4$ & $844.8^{a} \pm 160.2$ & $949.7^{\mathrm{a}} \pm 191.4$ \\
\hline Faeces excreted (g DM/day) & $375.9^{\mathrm{a}} \pm 22.6$ & $365.8^{\mathrm{a}} \pm 61.2$ & $343.1^{\mathrm{a}} \pm 41.5$ & $308.1^{\mathrm{a}} \pm 50.9$ \\
\hline DM intake (g/kg W W.75/day) & $78.4^{\mathrm{a}} \pm 6.5$ & $75.1^{\mathrm{a}} \pm 9.2$ & $73.8^{\mathrm{a}} \pm 7.3$ & $73.9^{\mathrm{a}} \pm 8.9$ \\
\hline
\end{tabular}




\section{Conclusions}

The sun-dried and coarsely ground Opuntia cladodes induced a higher water intake. Although more definitive research is needed, it is concluded that the wetter faeces produced by the wethers on diets T12, T24 and T36 was not diarrhoea induced by the Opuntia cladodes, but the result of larger quantities of water that were not reabsorbed from the lower digestive tract.

\section{References}

AOAC, 2000. Official Methods of Analysis. Volume 1. $17^{\text {th }}$ ed. Association of Official Analytical Chemists, International ${ }^{\circledR}$. AOAC International, Gaithersburg, Maryland.

Batista, A.M.V., Mustafa, A.F., Santos, G.R.A., de Carvalho, F.F.R., Dubeux Jr, J.C.B., Lira, M.A. \& Barbosa, S.B.P., 2003. Chemical composition and ruminal dry matter and crude protein degradability of spineless cactus. J. Agron. Crop Sci. 189, 123-126.

Ben Salem, H., Nefzaoui, A. \& Ben Salem, L., 2002. Nitrogen supplementation improves the nutritive value of Opuntia ficus-indica F. inermis-based diets and sheep growth. Eds. Nefzaoui, A. \& Inglese, P., Proc. $4^{\text {th }}$ Int. Congress on Cactus Pear and Cochineal. Acta Hort. 581, 317-321.

Ben Salem, H., Nefzaoui, A. \& Ørskov, E.R., 1996. Effect of increasing level of spineless cactus (Opuntia ficus-indica var. inermis) on intake and digestion by sheep given straw-based diets. Anim. Sci. 62, 293-299.

Cárdenas, A., Higuera-Ciapara, I. \& Goycoolea, F.M., 1997. Rheology and aggregation of cactus (Opuntia ficus-indica) mucilage in solution. J. PACD. 2, 152-159.

Claassens, A.S. \& Wessels, A.B., 1997. Eds. Inglese, P. \& Brutsch, M.O. Proc. $3^{\text {rd }}$ Int. Congress on Cactus Pear and Cochenille. Acta Hort. 438, 83-95.

De Kock, G.C. \& Aucamp, J.D., 1970. Spineless Cactus: The farmer's provision against drought. Department of Agricultural Technical Services. Pretoria. Leaflet no. 37.

Felker, P., 1995. Forage and fodder production and utilization. In: Agro-ecology, cultivation and uses of cactus pear. Eds. Barbera, G., Inglese, P. \& Pimienta-Barrios, E., FAO Plant Production and Protection Paper 132. Food and Agriculture Organization of the United Nations, Rome. pp. 144-154.

Goering, H.K. \& Van Soest, P.J., 1970. Forage Fiber Analysis. U.S.D.A. Agricultural Handbook, No. 379.

Leco, 2001. FP-528 Protein/Nitrogen Determinator. Instruction Manual, Version 1.2. Leco® Corporation.

Mindt, L., Saag, K., Sanderson, G.R., Moyna, P. \& Ramos, G., 1975. Cactaceae mucilage composition. J. Sci. Food Agric. 26, 993.

Nefzaoui, A. \& Ben Salem, H., 2000. Opuntia: A strategic fodder and efficient tool to combat desertification in the WANA region. Ed. Inglese, P., CACTUSNET Newsletter 2000. pp. 2-24.

Pretorius, C.C., Rethman, N.F.G. \& Wessels, A.B., 1997. Invloed van besproeiingspeil op die opbrengs en voedingswaarde van die cultivars Opuntia ficus-indica as veevoer. Applied Plant Sci. 11(2), 53-55.

Robertson, J.B. \& Van Soest, P.J., 1981. The detergent system of analysis and its application to human foods. In: The Analysis of Dietary Fiber. Eds. James, W.P.T. \& Theander, O., Dekker, New York.

Sáenz, C., Sepúlveda, E. \& Matsuhiro, B., 2004. Opuntia spp mucilage’s: A functional component with industrial perspectives. J. Arid Environ. 57, 275-290.

SAS, 2001. SAS/STAT ${ }^{\circledR}$ Software: Usage and reference, Version 6.04. SAS Institute Inc., Cary, N.C., USA.

Sudzuki Hills, F., 1995. Anatomy and Morphology. In: Agro-ecology, Cultivation and Uses of Cactus Pear. Eds. Barbera, G., Inglese, P. \& Pimienta-Barrios, E., FAO Plant Production and Protection Paper 132. Food and Agriculture Organization of the United Nations, Rome. pp. 28-35.

Tegegne, F., 2002a. Fodder potential of Opuntia ficus-indica. Eds. Nefzaoui, A. \& Inglese, P., Proc. $4^{\text {th }}$ Int. Congress on Cactus Pear and Cochineal. Acta Hort. 581, 343-346.

Tegegne, F., 2002b. In vivo assessment of the nutritive value of cactus pear as a ruminant feed. Eds. Nefzaoui, A. \& Inglese, P., Proc. $4^{\text {th }}$ Int. Congress on Cactus Pear and Cochineal. Acta Hort. 581, 323328.

Terblanche, I.L., Mulder, A.M. \& Nel, L.P., 1972. 'n Knypie vis by die turksvy. Boerdery in S.A. Julie 1972.

Zeeman, D.Z., 2005. Evaluation of sun-dried Opuntia ficus-indica var. Algerian cladodes in sheep diets. MSc Agric. thesis. University of the Free State, Bloemfontein. 